\title{
HÂBİL İLE KÂBİL KISSASI VE MİNYATÜR SANATINA YANSIMALARI
} TALE OF CAIN AND ABEL AND ITS REFLECTIONS ON ART OF MINIATURE

\section{Elif BAYRAK KAYA*}

ÖZ: Hâbil ile Kâbil'in kıssası hakkındaki en doğru bilgileri, Kuran-ı Kerim'den ediniyoruz. Kuran'ın yanı sıra diğer tek tanrılı ilahi dinlerin kutsal kitaplarında da Hâbil ile Kâbil kıssası anlatılmaktadır. İlâhi kitaplarda aktarılan bilgiler, hikâyenin halk arasında bilinen ve anlatılan metnini oluşturmaktadır. Tüm bu bilgiler özünde aynı olmakla beraber, detaylarda birbirinden farklılıklarda göstermektedir.

Bu kıssanın edebi metinleri süsleyen konusu, görsel sanatlar açısından da merak uyandırıcı ve dikkat çekici olmuştur. Minyatür sanatındaki, dini konulu eserler incelendiğinde Hâbil ile Kâbil'in kıssasını anlatan pek çok örnek görmekteyiz.

Hâbil ile Kâbil'in kıssasını anlatan minyatür örnekleri incelenerek bir karşılaştırma yapılmıştır. Bu örnekler farklı dönem ve üsluplarda yapılmış olmasına karşın, kompozisyon düzenleri ve kurgularının birbirleriyle büyük benzerlikler gösterdiği görülmektedir. $\mathrm{Bu}$ durumun sebepleri üzerinde duracak olursak, kompozisyonları çizen nakkaşların kıssayı yorumlarken, kutsal kitaplar ve rivayetlerden edindikleri bilgilerin odak noktalarını net bir biçimde, birbirleri ile çelişmeden vurguladıklarını söyleyebiliriz. Bir diger sebepse, kıssayı yorumlayan nakkaşların birbirlerinden etkilenerek aynı odak noktasını benzer bir kompozisyon düzeni ve kurgusu içinde çizmiş olmalarıdır.

Hâbil ile Kâbil'in kökeni, kutsal kitaplar ve rivayetlerin anlatıları, Hâbil ile Kabil'in arasındaki mesele, çözüm yolları, Allah'a sundukları sungu, Kabil'in cinayeti, kargaların dersi gibi konular, literatürden araştırılarak aktarılmıştır. Bunun yanı sıra, kutsal kitaplarda kıssa hakkında verilen bilgilerin benzer ve farklı yönleri üzerinde durularak, yapılan değerlendirmelerin aktarımı sağlanmıștır.

Anahtar Kelimeler: Hâbil ile Kâbil, sungu, karga, Hz. Âdemin iki oğlu, minyatür sanatı.

ABSTRACT: We learn the most accurate information on the tale of Cain and Abel from Quran. The holy scriptures of other monotheistic religions, besides Quran, also cite about the tale. The information and content that holy scriptures render form the content of the tale known and told among public. The information and content told are essentially identical while there are minor differences in details.

The theme and plot of this tale have always attracted visual arts. We come up a number of works that describe the tale of Cain and Abel when investigating the works with religious motives in the art of miniature.

This study involves a comparative work exploring the works of miniature depicting the tale of Cain and Abel. It has been found that these works demonstrate significant resemblances in terms of their composition layouts and constructs though they were works of different ages and styles. This can stem from the fact that the miniaturists placed the focus on the same points of

\footnotetext{
* Öğr. Gör. Dr. - Isparta Uygulamaları Bilimler Üniversitesi Gönen Meslek Yüksekokulu El Sanatları Bölümü Mimari Dekoratif Sanatlar Anabilim Dalı / Isparta elifbayrakkayaart@gmail.com (ORCID ID: 0000-0003-0241-3805) 
information that they derived from the Holy Scriptures and stories without any fail while interpreting the tale. Another reason behind the resemblances could be the fact that the miniaturists that interpreted the tale stayed under the influence of each other and put the focal point on the same composition layouts and constructs.

The miniatures involved descriptions of the origins of Cain and Abel, the narrations of Holy Scriptures and stories, the dispute between Cain and Abel, the ways to settle the dispute, their gift to God, description of crow and the murder of Cain. The study also involves the similarities and differences of the information presented in the Holy Scriptures and stories as well as the wrap-up of all information.

Keywords: Cain and Abel, gift, crow, two sons of Prophet Adam, art of miniature.

\section{Giriş}

Hâbil ile Kâbil'in öyküsü, Âdem ve Havva'nın İblisin oyunu ile cennetten ayrılmaları ve yeryüzüne inmeleri ile başlar diyebiliriz. Âdem ve Hava ayrı ayrı indirildikleri yeryüzünde, uzun bir müddet birbirlerini ararlar ve sonunda Arafat denilen yerde buluşup, bir araya gelerek evlat sahibi olurlar. Tüm insanoğlunun ilk atası Âdem ve Havva olarak bilinmekte ve inanılmaktadır.

Âdem, Havva, İblîs ve yılan Allah tarafından yeryüzüne indirildiler. Allah, Âdem'i Hindistan'a, Havva'yı Cidde'ye indirdi. Yere indirildikten sonra Havva'yı aramaya koyulan Âdem, onu Arabistan'da buldu. Her ikisinin buluştukları yere de Müzdelife denilmiştir (Şola, 2015: 209).

Öykünün Tekvin'deki devamında (bölüm 4) Âdem'le Havva'nın yeryüzündeki yaşama nasıl adapte oldukları hakkında bir bilgi verilmeden doğrudan Kain(Kabil)'in doğumuna geçilir (Batuk, 2009: 55-56).

Âdem ile Havva'nın çocuklarına gelince Taberi Tarihi'nde çeşitli kaynaklara göre bunların sayısı ve çocukların adları üzerine bilgi vermektedir. Bir söylenceye göre Âdem ile Havva'nın 120 çocuğu olmuştur. İlk doğumda Kabil ile ikizi Klima, en sonuncu doğumda ise Abdül'Imugis ile Emetü'l-mugis doğmuştur. Bir başka söylenceye göre 40 ikizleri olmuştur. Bunun yirmisi erkek, yirmisi kızdır. Aynı kaynakta bunların adları da bilinmektedir: Erkeklerden on beşinin, kızlardan da dördünün adı bilinmektedir. Önce Kabil ve ikizi Klima, Habil ile ikizi Liyuza, kızı Eşut ile ikizi, Şit (Şit) ile ikizi (And, 2007: 98).

Bir tek nefisten yaratılan Âdemle Havva'dan insanlık nasıl oldu da bu denli çoğaldı sorusu akıllara gelmektedir. Âdem ve Havva'nın çocukları, hep ikiz olarak dünyaya geldiği söylenir. Bu konuda "müfessirlerin beyanına göre Âdem'in her doğumda biri erkek biri kız olmak üzere ikiz çocuğu olurdu. Bir önce doğan erkek, bir sonra doğan kızla evlenirdi. O zaman başka insan olmadığı için bu şekilde evlenmek zorunlu idi. Nihayet Âdem'in Habil ve Kabil adında iki oğlu oldu. Kabil'in ikizi olan kız, Habil'in ikizinden daha güzel olduğu için Kabil ikizini Habil'e vermeyip onunla kendisi evlenmek istedi. Babaları Allah'a kurban sunmalarını, hangisinin kurbanı kabul 
edilirse onun haklı olacağını söyledi. Kurbanın kabulüne işaret de gökten inecek bir ateşin kurbanı yakması idi (Ateş, 1995: 770-771'den akt. Dikbıyık, 2018: 526).

Hz. Âdem öyküsünde en önemli oluntu Habil ve Kabil 'le ilgilidir. Birçok sanat ve edebiyatta, özellikle tiyatro eserlerinde, bu arada taziyelerde çok işlenmiş bir konudur. Bu insanlık tarihinde ilk öldürme olayıdır. Tevrat'ta anlatılmaktadır. (Tekvin IV, 3-16). Kuran 'da ise biraz değişik bir biçimde anlatılmaktadır (Maide S, 27-34). Buna göre iki kardeş Tanrı'ya birer kurban sunmuşlardı. Tanrı birinin kurbanını kabul etmiş, ötekini geri çevirmiştir (And, 2007: 99).

Yeryüzünde bilinen toplumsal boyutlu ilk günah (suç eylemi) Âdem ve Havva'nın oğulları Habil ve Kabil arasında meydana gelmiştir. Habil ve Kabil isim olarak Kuran'da geçmese de Âdem'in iki oğlu olarak zikredilmektedir (Dikbıyık, 2018: 523-524).

Hâbil-Kâbil kıssası Kur'an'da sadece bir yerde zikredilmiştir. Kıssanın oldukça kısa ve özlü bir şekilde aktarıldığı 5/Mâide 27-31. ayetler, genelde Ehl-i Kitab'a, özelde de Yahudilere yönelik beyanları muhtevi bir pasajda yer almakta ve söz konusu (kıssa, Tekvin kitabındaki IV/1-16. pasajlara zımnen gönderme yapan bir hitapla şöyle başlamaktadır: Onlara (Ehl-i Kitâb’a veya sadece Yahudilere) bir gerçeğin ifadesi olarak Âdem'in iki oğlunun kıssasını anlat. Hani, her ikisi birer kurban sunmuşlardı da birinin kurbanı kabul edilmiş, ötekininki kabul edilmemişti. [Kurbanı kabul edilmeyen Kâbil], "Seni mutlaka öldüreceğim" demişti. [Kardeşi Hâbil] ise, "Unutma ki Allah sadece kendisine karşı saygılı olup sorumluluk bilinci taşıyanların (kurbanını) kabul eder. Beni öldürmek için el uzatsan da ben seni öldürmeye kalkışmam. Çünkü ben âlemlerin rabbi olan Allah'tan korkarım. [Ĕğer beni öldürürsen] dilerim hem kendi günahlarını hem de benim günahlarımın [yükünü yüklenir,] böylece cehennemin yolunu tutarsın! Zira zalimlerin cezası budur!" demişti. Kâbil'deki bencilik, kendisini kardeşi [Hâbil'i] öldürmeye sevk etti ve nihayet onu öldürdü. Böylece, hüsrana uğrayanlardan oldu (Öztürk, 2004: 148).

Kuran'da Hâbil ve Kâbil kıssasının devamında Kâbil'in kardeșini öldürdükten sonra, Hâbil'in cesedini, ne yapacağını bilmeyerek, çaresizce ortalıkta dolaşması şu şekilde aktarılır.

Maide, 31-Derken Allah bir karga gönderdi, yeri deşiyordu ki ona kardeşinin cesedini nasıl örteceğini göstersin, eyvah, dedi: şu karga kadar olup da kardeşimin cesedini örtemedim ha! Artık peşimanlığa (pişman) düşenlerden oldu (Yazır, 1979: 1652).

Kuran-ı Kerim'de Kâbil'in pişman olanlardan olması açıkça belirtilmiş, ancak Kâbil gibi günahsız bir insanın ölümüne sebep olan herkesin cezalandırılacagıda bildirilmiștir. Kâbil, Hâbil 'i öldürerek ilk insanın ölümüne neden olmuş, böylelikle Kâbil kardeşini öldüren ve cinayet işleyen ilk insan olmuştur. 
Kur'an'da bu şekilde nakledilen kıssa, İslam tefsir ve tarih kitapları ile kısas-ı enbiya edebiyatındaki çeșitli rivayetlerde daha da detaylandırılmış ve bu detaylar çok sayıda mitolojik unsurla zenginleştirilmiştir(Öztürk, 2004: 149)

Habil-Kabil olayı ile ilgili Kuran'daki anlatımlara benzer, Kitabı Mukaddes'de de bilgilere yer verilmektedir: “...Ve Habil koyun çobanı oldu, fakat Kâin çiftçi oldu. Ve kâin günler geçtikten sonra toprağın semeresinden Rabbe takdime getirdi ve Habil kendisi de sürünün ilk doğanlarından ve yağlarından getirdi. ve Rab, Habil'e ve onun takdimesine baktı; fakat Kâine ve onun takdimesine bakmadı. ...Ve vakit oldu ki kırda oldukları zaman Kain kardeşi Habil'e karşı kalktı ve onu öldürdü". Bundan sonra Rab Kain'e toprak tarafından lanetlendiğini bildirir ve onu kovar, sonra da Kain bir kaçak ve serseri gibi dolaşır (Dikbıyık, 2018: 525).

Kābil Hâbil'i öldürünce yeryüzü yedi gün boyunca sallanır ve daha sonra toprak Hâbil'in kanını emer. Allah Kâbil'e, "Kardeşin Hâbil nerede?" diye sorar; Kābil, "Bilmiyorum, ben onun bekçisi değilim" der. Bunun üzerine Allah, "Kardeşinin kanı topraktan bana sesleniyor; kardeşini niçin öldürdün?" der; Kābil' de, "Eğer onu öldürdüysem kanı nerede?" diye karşılık verir. Bundan sonra Allah yeryüzüne kan emmeyi yasaklar. Tarih ve tefsir kitaplarında yer alan bu tür rivayetler genellikle yahudi ve hıristiyan menșelidir. Kābil ile ikizinin cennette, Hâbil ile ikizinin yeryüzünde doğdukları, iki kızdan daha güzel olanı kimin alacağını tesbit için kurban takdim ettikleri, Hâbil'in öldürülmesiyle ilgili olarak Kābil'in İblîs'i örnek aldığı şeklindeki rivayetler. Tevrat tefsirlerinde de yer almaktadır. Apokrif kabul edilen, hem Süryânîce hem de Arapça nüshaları bulunan "Hazineler Mağarası" (La caverne des trésors) adlı kitapta da aynı bilgiler bulunmaktadır (URL-1).

Hâbil-Kābil kıssasına dair Tevrat'ta yer alan ayrıntılı bilgiler arasında tutarsızlıklar olduğu görülür. Meselâ Tevrat’a göre, Kābil-Hâbil'i öldürdükten sonra insanların kendisinden öç almasından korkmuş ve "Kim beni bulursa öldürecek" demiştir (Tekvîn, 4/14). Halbuki Tevrat'ın aynı bölümünde, o sırada yeryüzünde yalnızca Âdem ve Havvâ ile oğulları Hâbil ve Kābil'in mevcut olduğu kaydedilmektedir. Tevrat'la ilgili tenkidî inceleme faaliyeti ve ilmî araştırmalar, Hâbil-Kābil kıssasının birbirinden tamamıyla farklı iki ayrı kaynak ve rivayetin bir araya getirilmesiyle oluştuğunu ortaya koymuştur (URL-1).

Tevrat'ta anlatılan Hâbil-Kābil kıssasın da, Kabil toprakla uğraşan bir çiftçi iken, Habil hayvancllıkla uğraşmaktadır.

Sümer mitolojisinde aynı temaya rastlanır ve Hâbil-Kābil kıssası, çoban tanrı Dumuzi ile çiftçi tanrı Enkimdu'nun tanrıça İştar'ın sevgisini kazanabilmek için yarışa girdiklerini, armağanlar sunduklarını anlatan "Dumuzi ile Enkimdu" efsanesine benzemektedir Kitâb-ı Mukaddes'te ve Kur'ân-ı Kerîm'de yer alan bu kıssaya benzer bazı unsurların eski medeniyetlerin mitolojilerinde de bulunması, bu kıssada anlatılanların 
efsanevî olaylar ve kişiler olduğunu göstermez. Aynı hadisenin uzun tarihî seyir içerisinde çeşitli çevre ve kültürlerde farklılık kazanması tabiidir ve bu değişik varyantların temelde mevcut bir tarihî hadiseye bağlı olduğunu gösterir ki ilâhî dinlere göre insanlığın başlangıcl, söz konusu kıssa kahramanlarının da atası olan Âdem ile Havvâ'dır. Kıssanın Tevrat'taki şekli Kur'an'a göre çok ayrıntılıdır ve muhtemelen kutsal metin yazarı ulaşıp derleyebildiği çeşitli rivayetleri ve farklı unsurları hikâyeye katmıştır (URL1).

\section{Hâbil ile Kâbil'in Anlaşmazlığa Düştükleri Konu}

Kuran-ı Kerim'de Hâbil ve Kâbil arasındaki meselenin ne yada neler olduğu bildirilmemiştir. Buna karşın aralarında bir anlaşmazlığın çıktığı ve bu anlaşmazlığı çözmek için her ikisininde Allahü teâlâ'ya kurban sundukları bildirilmiştir. Allahü teâlâ'; Hâbil ile Kâbil'in sunumlarından, Hâbil'in sunumunu kabul etmiş, Kâbil'in sunumunu ise reddetmiştir.

Hâbil ile Kâbil'in anlașmazlığa düştükleri konu İslam literatüründe "kız meselesi" Yahudi literatüründe ise "toprak" olarak sunuluyor (Dikbıyık, 2018: 526).

İnsan oglunun ilk cinayetini işleyen, Hz. Âdem'in oglu Kâbildir. Kuran1 Kerim'de "günahsız masum birini öldüren kişi tüm insanlıgı öldürmüş gibidir" diye aktarılır. Bu sebeptendirki Kâbil'in tüm insanlıgı öldürmüş gibi bir günahı yüklenmiş olması, bu günahı işleyenlere bir ders niteligindedir.

Allah'ın Adem'i yaratması ve meleklere Adem'e secde emrini vermesiyle, kıskanarak Ademin üstünlügünü kabul etmeyen Şeytan (İblis) isyan ederek, Allaha karşı çıkması ve bulundugu konumdan indirilmesi yine, Yüce Allah'ın Habil' in sungusunu kabuledip Kabil' in sungusunu reddetmesi üzerine, Kabil de kıskançlık ve öfke içersinde Habili öldürmesi ve kendini suçlu duruma düşürmesi ile paralellik göstermektedir. İnsanlık için; Hâbil Allaha itaat, teslimiyet, masumiyet ve iyiliğin simgesi olurken, Kâbil Allah'ın rızasına isyanın, kıskançlıgın ve kibirin sembolü olmuştur.

\section{Sungu'nun Ne Oldugu Konusundaki Rivayetler}

Yine sundukları kurbanın ne olduğu konusu Kuran'da yer almamakta bu konuda Yahudi ve İslam literatüründe geniş bilgilere rastlanmaktadır (Dikbıyık, 2018: 526).

Kuran-ı Kerim'de Hâbil ile Kâbil'in anlaşmazlıga düştügü konunun ne oldugu bildirilmedigi gibi, Habil ile Kabilin Allah 'a sungusunun da ne oldugu bildirilmemiştir. Yine Kuran-ı Kerim'de (Maide-27) “Hani her biri birer kurban sunmuşlardı" şeklinde ifade edilmekte fakat kurbanın ne oldugu aktarılmamaktadır. Bunun yanı sıra, Allah'ın sunguyu kabulü konusundaki rivayet şu şekildedir.

Tanrının gönderdiği beyaz ateş eğer sönerse sunguyu kabul etmediğini, sunguyu yakarsa kabul ettiğini gösteriyordu (And, 2007: 101). Hâbil'in sungusu semiz, genç bir sığırdı; Kâbil'inki ise bir demet buğdaydı. 
Kâbil ayrıca bu demetten iri bir başağı kendisi yemişti. Ateş gelerek Hâbil 'in sungusunu yaktı, Kâbil'inkini olduğu gibi bıraktı (And, 2007: 100).

Literatür kaynaklarından edinilen bilgilerin yanı sıra görsel sanatlar alanında ifade edilen resimsel anlatımlarda bu konuda oldukça önemlidir. Sessiz bir çığlık misali meydana getirdiği eserde Nakkaş, adeta haykırır düşüncesini. Sadece bu düşünce eseri yapan Nakkaş'a mı aittir yoksa toplumun değer yargıları ve genel inanışmış bilinmez ama Hâbil ile Kâbil kıssasını yorumlayan her Nakkaş, bu bilgiyi eseri vasıtasıyla ifade ve ifşa eder. Görsel anlamda minyatür sanatındaki Hâbil ve Kâbil kıssasının yorumlarına genel manada bakıldığında, Sungunun ne olduğu konusunda çok az bilgiye rastlamaktayız. Birkaç örnekte sungu "kurban" (sığır, keçi vb. hayvan) olarak tasvir edilmiş, genel anlamda bu detaya girilmemiş olduğunu görüyoruz. Sungunun ne olduğu hakkında, Kuran-ı Kerim'de bir bilgi aktarımı yapılmasından dolayı, Osmanlı ve İslâm resmi diye adlandırılan minyatür sanatını uygulayan Nakkaşlar, eserlerinde "sunguyu" yorumlamak ve resmetmekten bilhassa kaçınmış oldukları söylenebilir.

\section{Hâbil ile Kâbil Kıssasının Minyatür Sanatına Yansımaları}

Hz. Âdem ve Hz. Havva'nın oğulları olan Hâbil ve Kâbil'in arasında bir sorun oluşur. Bu sorunun çözümü için Hz. Âdem, oğullarının Allah'a kurban sunmalarını ister. Bu konudaki kararı, yüce yaratıcının vereceğini bildirmesiyle, Hâbil ve Kâbil Allah'a kurban sunarlar. Kimin sungusunu ateş yakar ise, Allahü Teâlâ o sunguyu kabul etmiş diğerini reddetmiş anlamına gelmektedir. Allahü Teâlâ iki sungu ya da beyaz bir ateş gönderir. Habil'in sungusu yanar, Kabilinki söner.

Hâbil ile Kâbil başlarından geçen kıssa, Kur'an'da (El-Maide 5/27-31) ayetlerinde anlatılmaktadır. Kuran-ı Kerim'in yanı sıra Kitabı Mukaddes'te de anlatılan kıssa hem İslâm âlemindeki minyatürlerde hem de Avrupai yağlı boya resimlerde, konu olarak yer almıştır. Bu araştırmada; minyatür tasarım ve kompozisyonlar da sıkça rastladığımız, Hâbil ile Kâbil kıssasını anlatan bazı yorumlara değineceğiz.

Gerek Kur'an'ı Kerim'den gerek ise farklı ilahî dinlerin kitap ve öğretilerinden edinilen bilgiler ıșığında, Hâbil ile Kâbil kıssası, minyatür nakkaşlar tarafından defalarca yorumlanarak, beğeniye sunulmuştur. Nakkaş'ının kompozisyon bilgisi ve yeteneğinin yanı sıra olaya bakış açısını da sergileyen bu kıymetli yorumlar, araştırılıp, birkaçı seçilerek incelenmiş, resim okuma ve analiz yöntemleri uygulanarak, karşılaştırmalar yapılmıştır.

\section{Hâbil ile Kâbil Kıssasının İzlerini Taşıyan Minyatür Örnekler}

Hâbil ile Kâbil'in atası yani babası Hz. Âdem'dir. Bu bakımdan ilk olarak, onların bir nevi soy kütüğünü anlatan ve çağdaşları ile kıyaslandığında farklı bir ikonografi sergileyen minyatür "Zübdetü'tTevarih"te bulunmaktadır (Resim-1). Hz. Âdem ve Havva'nın içinde Habil ile Kabilinde yorumlandığı, ikiz çocukları ile görüntülenmiş olan minyatür örneği değerlendirmekle başlayabiliriz. 


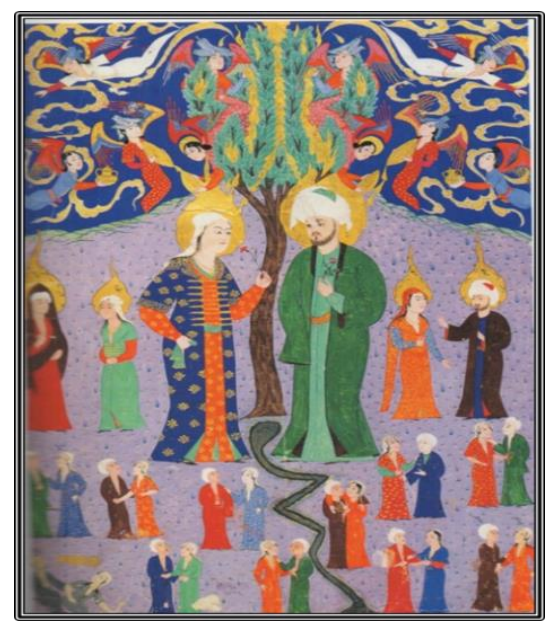

Resim 1: Ekim 1583 Tarihli, Lokman Aşuri - “Zübdet-üt Tevarih” İstanbul, Türk ve İslâm Eserleri Müzesi (Renda, 1977: 60).

Osmanlı minyatürlü yazmaları arasında ender rastlanan büyük boyutlu örneklerden biri olan Zübdet-üt Tevarih'in $(64.7 \times 41.3 \mathrm{~cm})$ içindeki 40 minyatürün çoğu tüm sayfayı kaplar. Osmanlı dinsel minyatürlerinin bilinen en erken örnekleri olması bakımından büyük önem taşır (Renda, 1997: 60).

Osmanlı nakkaşları, peygamber öykülerinde, gerçekçi ve gözetleyici bir yaklaşımları ile dikkati çekmektedir. Aslında bu dinsel konulu minyatürler, ne kompozisyon düzeni, nede figür işleyişi açısından, dönemin tarihsel minyatürlerinden farklı değildir. Yalnızca Peygamberlerin alev biçimindeki hareleri bu figürlerin insanüstü niteliklerini belirtir (Renda, 1997: 60).

İslam çevrelerinde Hz. Âdem'i yalnız veya Havva ile birlikte gösteren minyatürler vardır. Fakat ikiz çocukları bir arada görülmezler. Buradaki yorum, metni tüm gerçekliğiyle yansıtmaya çalışan (Resim-1) Osmanlı nakkaşının yaratısı olmalıdır (Renda, 1997: 60).

Zübdet-üt Tevarih'teki sahne dönemin tarih konulu resimlerindeki kompozisyon düzenini izler. 16. yüzyll Osmanlı giysileri içerisinde gösterilen Adem, Havva ve cocuklarının yan yana ve prarell sıralanması tarih konulu resimlerdeki gibidir. Yalnızca agacın üzerindeki melekler ve figürlerin haleleri resme dini bir içerik katar (bk.Resim-1). Başka bir deyişle, Adem ile Havva ve cocuklarının öyküsü tarihi olaylar gibi gerçekçi ve belgeleyici bir tutum ele almıştır (Bağcı vd., 2006: 132-133).

İkonografik açıdan bakıldığında öncesi ve çağdaş örneklerinde pek rastlanmayan bu kompozisyon düzeni ve kurgu oldukça dikkat çekici ve önemlidir. Zübdet-üt Tevarih te bulunan minyatürde, Âdem ile Havva'nın yeryüzünde birleşmesinin ardından, evlat sahibi olmalarını anlatan tasarımda, Âdem ile Havva 13 ikizi ile birlikte gösterilmektedir. Minyatür Resim-1'de; tam bir sayfa üzerine, dikdörtgen bir planda tasarlanan 
kompozisyonda, dış mekân betimlemesi yapılmıştır. Kompozisyonun merkezinde bir hayat ağacı, hayat ağacının hemen altından başlayan ve yaşamı simgeleyen hayat suyuna yer verilmiştir. İnce bir dere şeklinde zikzaklar oluşturarak zemin çizgisine kadar inmekte olan hayat suyu, kompozisyonu ikiye bölmüştür. Hayat ağacının solunda Hz. Âdem, sağında Hz. Havva ayakta birbirlerine dönük bir biçimde görüntülenmiştir. Hz. Âdem sol elinde bir gül, Hz. Havva ise sol elinde bir karanfil ile betimlenmiştir.

Havva'nın sağında yedi çift ve Âdem in solunda altı çift ikiz, karşılıklı ayakta görülmektedir. Kompozisyonun sağ alt köşesinde, Kâbil ve ikizi Klima görüntülenmiştir. Kâbil, ikizi Klima'yı belinden tutmuş çekiştirir bir hareket planında çizilmiştir. Bu sahne adeta tüm kompozisyonun, Kâbil'in bu inat ve zorbalığını anlatmak için tasarlanmış olduğu hissi uyandırmaktadır.

Hz. Âdem ve Hz. Havva'nın başlarında kutsallık ifade eden alevli harelerin, ilk sırada olan, ikiz evlatlarının başlarında da görülmektedir. Figürler resmedildikleri dönemin tarzını yansıtan, Osmanlı kılık ve kıyafetleri içinde betimlenmiştir. Kadınların başında anneleri $\mathrm{Hz}$. Havva'nınki gibi beyaz örtü görülürken, erkeklerin başlarında ise babaları Hz. Âdem in başında görülen Osmanlı sarığı ile resmedilmişlerdir. Figürlerin donuk ve ifadesiz olduğu söylenebilir.

Gökyüzünde bulutlar arasında uçan altı melek figürü simetrik oluşturacak biçimde çizilirken, gökyüzünü iki eşit parçaya bölen hayat ağacının yaprakları arasına gizlenmiş, yine simetrik yerleștirilmiş dört kanatlı melek figürü alanı renklendirirken, kompozisyona dini bir misyonda yüklemiştir.

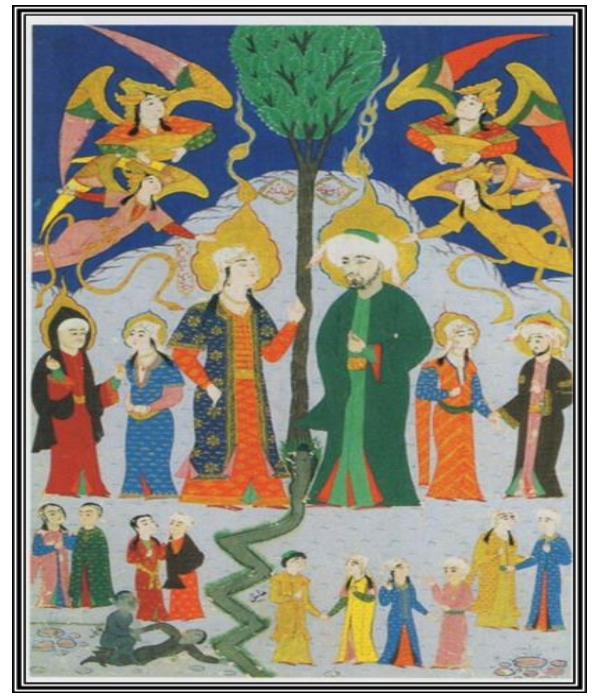

Resim 2: Âdem ile Havva ve Sekiz İkizi ( Zübdetü't-Tevarih, CBL 414). (And, 1998: 98).

Zübdetü't - Tevarih'te bulunan ve üslup ve kompozisyon bakımından birbirine oldukça benzeyen diğer bir minyatür tasarım ise (Resim-2) 'de 
görülmektedir. Âdem ile Havva bu defa sekiz ikizi ile birlikte görüntülenmiştir. Minyatür kompozisyon tam bir sayfa üzerine, dikey dikdörtgen planında tasarlanmıştır. Dış mekân betimlemesi yapılan minyatürde, yine merkezde kompozisyonu ikiye bölen, bir hayat ağacı ve hayat ağacının altından başlayarak mekân çizgisine ulaşan, hayat suyuna yer verilmiştir.

Osmanlı kılık ve kıyafetleri içinde görüntülenen figürler, Kâbil ve ikizi dışında, karşılıklı birbirine dönük bir biçimde resimlenmiştir. Bu tasarımda da yine Kâbil ile ikizi Klima'ya sağ alt köşede yer verilirken, Kâbil'in evlenmek istediği ikizi Klima'yı yerde sürüklemekte olduğu görülür. Hayat suyunun hemen diğer yakasında Kâbil ile Kilma’nın hizasında sarı giysiler içerisinde Hâbil ve ikizi görüntülenmiştir.

Her iki minyatür tasarım Resim-1 ve 2'ye bakıldığında, Kâbil'in hakkına razı olmayarak, ikizi Klima'yı çekiştirdiği ve zorladığı görülmektedir. Figürler yine donuk ve ifadesizken, Resim-1'e göre daha sade çizilen tasarımda, gökyüzündeki melekler yine simetrik bir biçimde yerleștirildiği görülür.

\section{Hâbil ile Kâbil Kıssasının Anlatan Minyatür Örnekler}

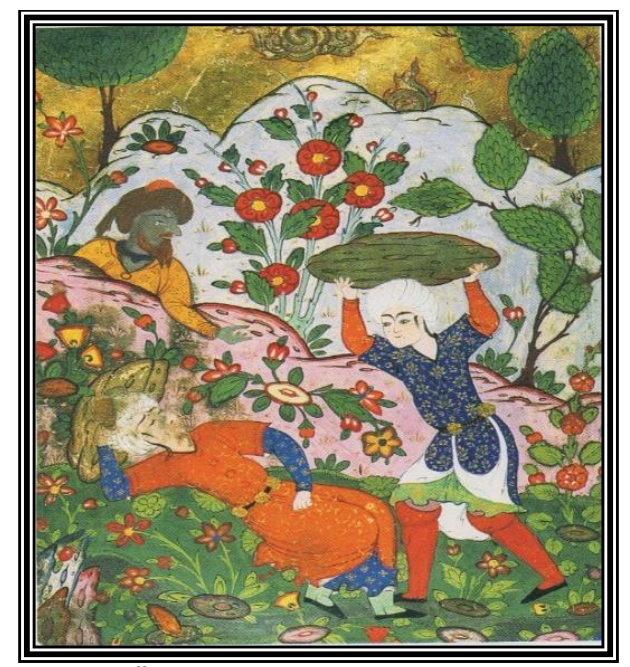

Resim 3: Kabil'in Habil'i Öldürmesi (Falname, TSM. 1703) (And, 1998: 99).

Nihayet bir gün Hâbil uyurken Kābil onu buldu ve bir taşla başına vurarak yirmi yaşındaki kardeşini öldürdü (URL-1).

Falname'de bulunan bu minyatürde, Hâbil ile Kābil'in Allah'a kurban sunmaları ve Kabil'in sungusunun kabul edilmemesi üzerine, büyük kıskançlık duyarak şeytana uyan Kabil'in, kardeşi Habil'i öldürmek istemesi konu alınmıştır. Dış mekân betimlemesi yapılan dikdörtgen planlı minyatür tasarımda, Hâbil ile Kâbil ve İblis görüntülenmiştir.

Kompozisyonun sağ alt köşesinde, Hâbil çimlere uzanmış, dizler hafif bükük sol kolu kucağında uyur vaziyette görüntülenmiștir. Hâbil'in başı 
büyük bir taş üzerinde, sağ eli ise başı ile taş arasında yastık vazifesi görmektedir. Uyuyan Hâbil'in ayak ucunda, Kâbil iki eliyle başının üzerine kaldırdığı büyük bir taşı Habil'in başına atmak üzere iken, ayakta tasarlanmıştır. Kompozisyondaki figürler tasarlandığı dönemin, Osmanlı kılık ve kıyafetlerini yansıtmaktadır. Hâbil uyurken, kötü bir rüya görüyormuşçasına yumduğu gözleri ve yüz ifadesi ile sıkıntılı bir hal içerisinde resmedilmiştir. Hâbil in aksine, Kâbil ve İblis boş bakışlarla ifadesiz ve donuk bir anlatım sergilemektedir.

Tam olay anının betimlendiği tasarımın yeşil alanın bitiminden başlayan, pembe tepenin arkasında, sol eli Kâbil'e doğru uzanmış, İblis görüntülenmiştir. İblis'in teni oldukça koyu tasarlanırken, başında kahverengi bir sarık, boynunda ise siyah urgan ile kısık gözlü, iri burunlu ve kızıl sakallı bir insan tipinde betimlenmiştir. Arka planda açık mavi bir tepe ve tepenin üzerine yerleştirilen yeşil yapraklı ağaçlar ile mekâna küçük bir koru havası verilmiștir. Tepenin bitiminden başlayan altın gökyüzü, yine altın bulutlar ile süslenmiştir. Kompozisyonun her yerine serpilen çeşitli cinste çiçeklerle alan hareketlendirilmiştir. Tasarımın nerdeyse tamamında kullanılan canlı ve berrak renkler tasarıma duru bir güzellik katmıştır.

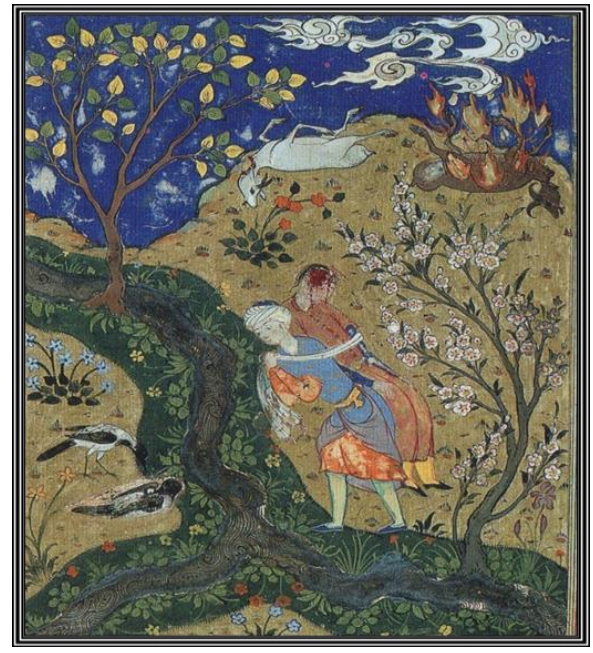

Resim 4: Ms. T-8. Habil ile Kabil, Kısasü'l-Enbiya (Milstein vd.,1999, Resim-15).

Kâbil kardeşini öldürdükten sonra, cesedi ne yapacağını bilemez ve sırtına alıp dolaşır. Ne kadar dolaştığı ile ilgili türlü rivayetler vardır. Kâbil'in Hâbil'in cesedini sırtında taşıma süresini bazı rivayetler aylarca, bazıları ise bir sene oldugunu ifade eder. Tam olarak bu sürenin ne kadar olduğu bilinmez, Kuran'da bildirilmemiştir. Kuran-ı Kerim'de, cesedin nasıl gömülecegi karga aracılıgı ile Kâbil'e ögretildigi anlatılır. Allah kargalar ile cesedi ne yapacağını bilemeyen Kâbil'e, yol göstermiştir. Kâbil karganın yaptığını görünce üzülüp "karga kadar olamadım yazık bana" diyerek kendini hayvandan aşağı görmüş ve pişman olmuştur. 
Resim-4'teki minyatür tasarımda, Allah'ın emri ile karganın Kâbil'e kardeşini nasıl gömeceğini, ögretilmesi anlatılmaktadır. Dış mekân betimlemesi yapılan minyatürde, Kâbil ile Hâbil'in yanı sıra iki karga ve iki küçükbaş hayvan görüntülenmiştir. Kâbil öldürdüğü kardeşini sırtına bağlamış ne yapacağını bilmez bir biçimde dağ, bayır yürürken, Hâbil başından akan kanlarla eli yüzü kan revan içinde resmedilmiştir.

Kompozisyonun merkezinde iki kola ayrılarak akan, gümüş renkli bir dere betimlenmiştir. Derenin sağında iki karga, biri diğerini, eştiği çukura gömerken görülmektedir. Derenin diğer yakasında, sırtında Hâbil'in cesedini taşıyan Kâbil, olan biteni izlerken resmedilmiştir. Kâbil gözleri kargada, sırtındaki yükü bile indirmeden şaşkınlık ve hayret içinde, donakalmışçasına görüntülenmiştir

Minyatürün arka cephesi, zeminle birleșen ve zeminle aynı renkte olan alçak bir tepe ile verilmiştir. Tepenin üstünde, iki kurban (koyun veya keçi) başlarından kesilmiş bir biçimde yan yana görüntülenirken, yüce Allah'a, Hâbil ile Kâbil'in sunduğu iki sunguyu simgeleyen bu kurbanlardan biri ateș tarafından yanmış, diğeri olduğu gibi durmaktadır. Sağda ki Hâbil'in kabul olan sungusu üzerinde halen ateşin olması bize olay anının betimlendiğini göstermektedir. Minyatür sanatında farklı zaman ve mekânların eş zamanlı bir düzende ve aynı mekân içerisin de gösterilebilmeleri çok eski bir ikonografidir. Burada İslâm minyatür geleneklerinde görülen bu ikonografik kompozisyon kuralının tekrarını görmekteyiz.

Minyatürdeki figürler eserin yapıldığı dönemin Osmanlı kılık ve kıyafetini yansıtmaktadır. Bir bahar havasında çizilen mekân, bahar dalı ve yeşil yapraklı ağaçlarla görüntülenirken, çimenlerin üzerine çizilen renk renk çiçeklerle alan canlandırılmıştır. Koyu mavi gökyüzü açık renklerde boyanan kompozisyonu önplana çlkarırken, gökyüzündeki bulutlarla derinlik hissi uyandırılmıştır.

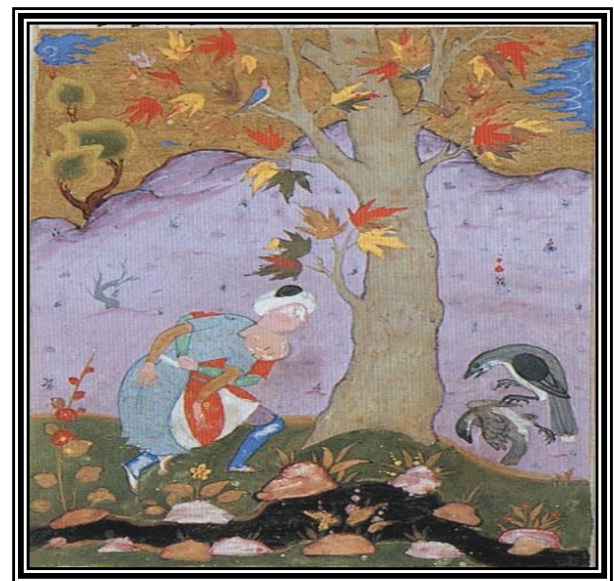

Resim 5: Ms. D. Habil ile Kabil, Kısasü’l-Enbiya. ( Milstein vd., 1999, Resim-6).

Resim-5'teki minyatürde yine, Allah'ın emri ile karganın, Kâbil'e kardeşini nasıl gömeceğini, göstermesini konu almıștır. Hâbil ile Kâbil 
dikdörtgen planlı bir kompozisyonda, dış mekân betimlemesi içerisinde görüntülenmiştir. Kâbil kollarını, Hâbil'in cesedinin beline sarmış, sürüklercesine taşırken tasvir edilmiştir.

Bir önceki tasarımda Hâbil'in başı kanlar içindeyken, bu tasarımda Hâbil'in başından yaralandığını gösteren bir ibareye yer verilmemiştir. Figürler yine Osmanlı kılık ve kıyafetleri içerisinde verilirken tiplemelerde, Osmanlıyı anımsatmaktadır. Kâbil'in başında Osmanlı sarığı görülürken, Hâbil'in muhtemelen başından düşmüş olan sarığı görülmez, Hâbil başı saçsız kel bir biçimde yorumlanmıştır.

Minyatürde, sadece gövdesi görünen dev bir çınar ağacı kompozisyonu ikiye bölmüştür. Çınar ağacının sağında Hâbil ile Kâbil solunda ise iki karga betimlenmiştir. Bir önceki minyatür tasarımda (Resim4) karga, ölen bir kargayı gömerken resmedilmiş, bu tasarımda ise, karga ayakları önündeki ölü kargaya bakar bir vaziyete görüntülenmiştir. Kâbil tam önünde gerçekleşen olayı izlemektedir.

Zemin çizgisinin hemen üzerinde, zemine paralel akan, şirin bir dere yerleştirilmiştir. Derenin kenarları taş ve bitkilerle tek sıra oluşturacak bir biçimde donatılırken, olayın cereyan ettiği yeşil alanın bitiminden, eflatun renkli bir tepe yükselmektedir. Arka zemini oluşturan eflatun tepenin zirvesinde bulunan yeşil yapraklı bir ağaç dışında, tepe birkaç cılız ot ile oldukça sade bir görünüm sergilemektedir. Ayrıca bir duvar misali düz çizilip boyanan tepe, tasarımdaki derinlik hissinin kaybolmasına neden olmuştur diyebiliriz.

Minyatür kompozisyon ikonografisinde göl ve akarsu boyamalarında görülen, gümüş kullanımı oldukça yerleşik bir kalıptır. Özellikle Osmanlı minyatürlerinde sıkça karşımıza çıkan bu boyama kalıbı; zaman içerisinde gümüş renginin kararması ile siyahlaşmaktadır (Resim-5.) Günümüzde uygulanan minyatür tasarımlarındaki, göl ve akarsu boyamalarında, gümüş' ün pek tercih edilmediği görülür. Altınla boyanan gökyüzünde, iki mavi bulut ve çınar ağacının renkli yaprakları atmosfere canlılık katmıştır.

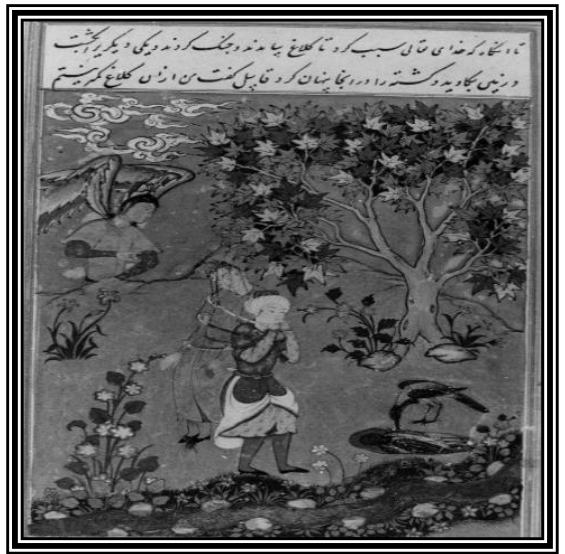

Resim 6: Hâbil ile Kâbil Peygamberler ("Zübdet-üt Tevarih” İstanbul, Türk ve İslam Eserleri Müzesi.) 
Resim-6'daki minyatürde yine; Kâbil'e kardeşini nasıl gömeceğini, kargalar vasıtasıyla öğretilmesi anlatılmaktadır. Dış mekân tasarımı yapılan kompozisyonda, tasarım ögeleri, dikey bir dikdörtgen alan içerisine yerleștirilmiştir. Minyatürde Hâbil, Kâbil, kanatlı bir melek ve iki karga olmak üzere beş figür tasarımına yer verilmiştir.

Kâbil sırtında Hâbil'in cesedi ile kompozisyonun merkezine yerleştirilmiştir. Kâbil dimdik sırtında taşıdığı cesedin ağırlığından zorlanmış gibi görülmezken, Hâbil'in cansız bedeni, başından akan kanlarla yorumlanmıștır. Yine Osmanlı tiplemelerini anımsatan figürler, Osmanlı kılık, kıyafetleri içinde verilmiştir. Figürlerdeki ifadesiz ve donuk bakışlar dikkat çekicidir.

Mekân çizgisiyle birleştirilen derenin etrafı, koyu zeminli çimenlerle çevrilerek, üzeri çiçeklerle donatılmıştır. Derenin hemen kenarında, Kâbil'in önünde, bir karganın çukur içerisindeki ölü karganın üzerine, gagası ile toprak attığı görülmektedir. Bu olayı izleyen Kâbil şaşkınlıktan sırtındaki cesedi dahi indirmeyi akıl edememiş bir hal içinde görüntülenmiştir.

Arka plan olarak çizilen, tepeciğin etekleri, olayın geçtiği dere kenarına kadar indirilmiştir. Tepenin ardında Kâbil'i ve kargayı izleyen iri kanatlı bir melek figürü görüntülenmiştir. Diğer bir minyatür örnek Resim3 'te benzer bir izleme sahnesinde, İblis'i görüyoruz. Kompozisyonun sol tarafına çizilen ve tasarımın üçte birini kaplayan çınar ağacı, alan doldurmak üzere çizilmiş hissi uyandırırken, gökyüzündeki beyaz bulutlar atmosfere canlılık katmıştır.

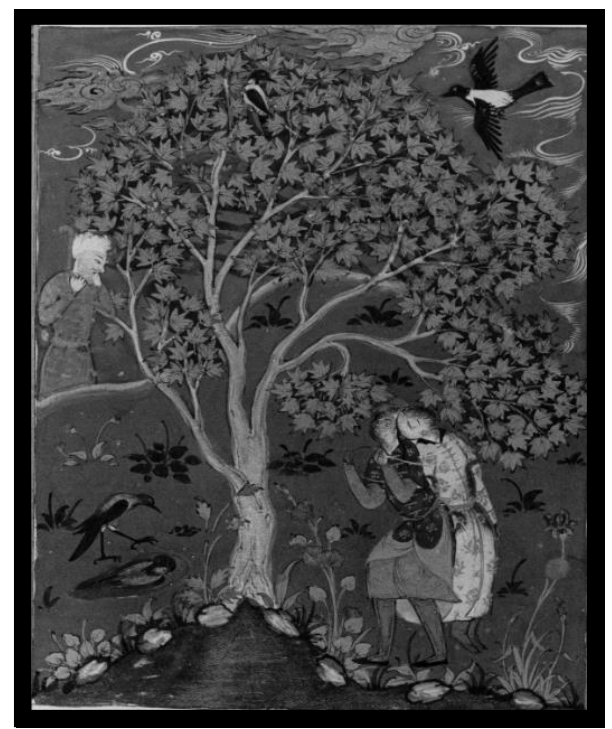

Resim 7: Habil ile Kabil Peygamberler (“Zübdet-üt Tevarih” İstanbul, Türk ve İslam Eserleri Müzesi).

Resim-7'de Kısasü'l-Enbiya'da bulunan bu minyatürde, yine karganın Kâbil'e ölü gömmeyi öğretmesi konu alınmıştır. Dış mekân tasarımı yapılan 
kompozisyon, dikey dikdörtgen planlıdır. Minyatür 'ün merkezinde büyük bir çınar ağacı kompozisyonu ikiye bölerken, çınar ağacının dibinden başlayarak, mekân çizgisine ulaşan küçük bir göl betimlenmiştir. Göl adeta çınar ağacının gövdesinden çıkarcasına tasarlanırken, gölün etrafı küçük kaya ve çiçeklerle donatılmıştır. Arka plan olarak tasarlanan tepenin etekleri, göl kıyısına kadar inerek, olayın geçtiği mekân oluşturulmuştur.

Kâbil yine sırtında, Kardeşi Hâbil'in cesedini taşırken, önüne çıkan kargayı izler bir vaziyette görüntülenmiştir. Çınar ağacının sağında, göl kenarında bir karga, ölen karganın yattığı çukurun içine ayakları ile toprak atarken resmedilmiştir. Yüzleri çok seçilemeyen figürlerin kılık, kıyafeti Osmanlı tarzını yansıtmaktadır.

Tepenin ardında olayları izleyen İblis resmedilmiş olup benzer bir görüntü Resim-3'te yer almaktadır. İblis orta yaşlı bir insan olarak betimlenirken, sağ eli ile boğazında takılı urganı tutması dikkat çekicidir. İblisin yorumlandığı pek çok minyatür tasarımda, karşımıza çıkan bu ikonografik görüntü yine tekrarlanmıştır diyebiliriz. Büyük kısmı çınar yaprakları ile kaplı gökyüzü, girift bulutlarla donatılarak, tasarımda yoğun ve yorucu bir görüntü oluşturulmuştur. Gökyüzünde uçan ve çınar dalına konan iki karga ile de nakkaş, kargaların doğal yaşam alanı olduğu hissi uyandırılmak istenmiş, diyebiliriz.

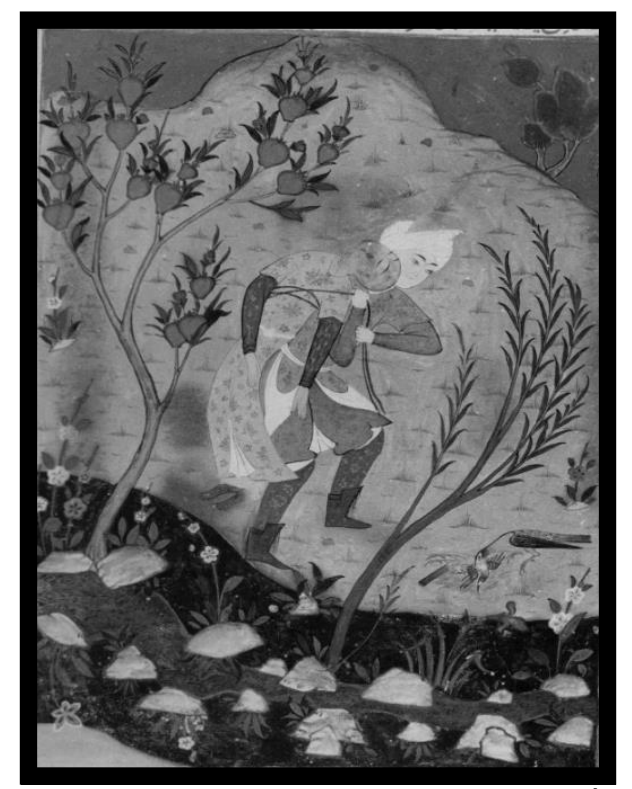

Resim 8: Hâbil ile Kâbil Peygamberler (“Zübdet-üt Tevarih” İstanbul, Türk ve İslam Eserleri Müzesi).

Kısasü'l-Enbiya'da bulunan bu minyatürde, Kâbil'e bir karganın, ölü gömmeyi öğretmesi konu alınmıştır. Dış mekânda dikey dikdörtgen planda tasarlanan minyatürde, dört figür görülmektedir. Zemin çizgisi üzerine, ince koyu yeşil çim alan çizilerek, yine alan içerisine, ince bir dere yerleștirilmiştir. Kompozisyondaki derenin etrafı taş ve çiçeklerle 
bezenirken, derenin üst yamacında, biri sağda diğeri tam ortada iki ağaç tasarımına yer verilmiştir.

Meyve ağacının hemen altında, sırtında kardeşinin cansız bedenini taşıyan Kâbil görüntülenmiștir. Kâbil'in sırtındaki yükün ağırlığı ile beli bükülmüş olmasına karşın, karşısına çıkan kargayı dört gözle izlerken resimlenmiştir. Osmanlı kılık kıyafetleri içinde betimlenen figürler güçlü bir çizim ile oldukça zarif verilmiştir. Kâbil'in ayakları önünde, ölü kargayı gömmek için, toprağı eșeleyen karga görüntülenmiştir.

Olayın geçtiği mekân, yine arka planı gösteren tepenin eteklerinde tasvir edilmiştir. Benzer örnekler Resim-4, 5, 6 ve 7'de görülmektedir. Tepenin üst yamacında görünen, yeşil yapraklı bir ağaç dışında, çizilen birkaç çiçek ve minik otla, kompozisyona sade bir görünüm kazandırılmıştır. Oldukça dar verilen gökyüzü, genel anlamda tasarımı boğmadığı gibi ilginçte bir derinlik katmıştır. Bu minyatür örnekte de Resim-5'teki gibi, Hâbil'in yüzü veya başında darbe aldığına dair bir iz bulunmamaktadır.

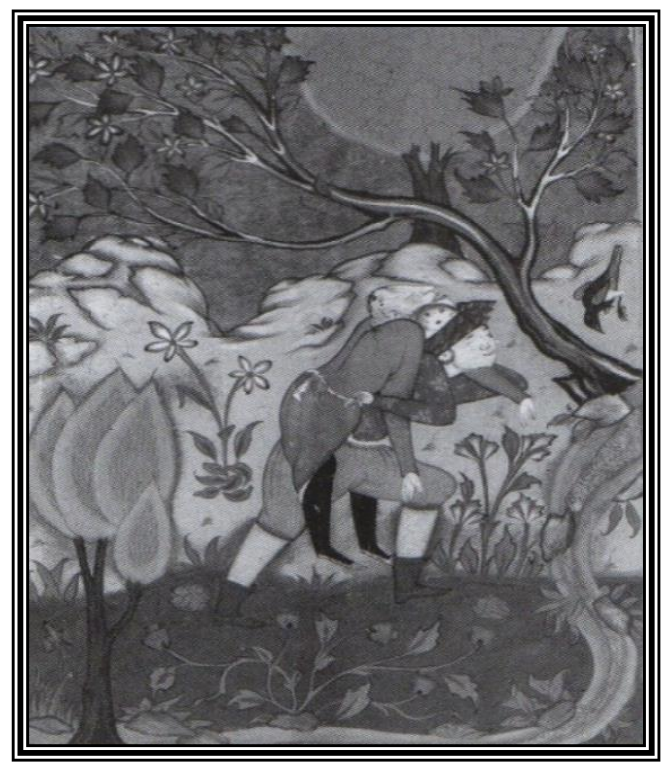

Resim 9: Resim 49 Ms. T-5. Habil ile Kabil, Kısasü'l-Enbiya. (Milstein vd. 1999, Resim: 49).

Resim-9'da Kısasü'l-Enbiya'da bulunan minyatürde, yine bir karganın Kâbil'e ölü gömmeyi öğretmesi konu alınmıştır. Minyatür tasarımda Hâbil ile Kâbil'in yanı sıra, yine iki karga görüntülenmiștir. Kompozisyon diğer örneklerde olduğu gibi, dış mekânda ve dikdörtgen planda tasarlanmıştır. Diğer minyatür örneklerden, üslup olarak farklı olan tasarımda, Selçuklu minyatür geleneklerinin izleri görülmektedir.

Geniş yeşil bir çim alan üzerinde figürler, kompozisyonun tam merkezine yerleştirilmiştir. Kâbil bu minyatürde de kardeşi Hâbil'in cesedini taşırken görülmektedir. Önüne çıkan kargayı merakla izleyen Kabil taşıdığı yükün ağırlı̆̆ını, oldukça hissettirmektedir. 
Karga, tepe üzerinde toprağı eșelerken betimlenmiştir. Bu minyatür örnekte, toprağı eşeleyen karganın arka mekândaki tepe üzerinde verilmesi ve Kâbil'in yüzünün kargaya dönük olmaması oldukça ilginç bir yorum olarak karşımıza çıkmaktadır. Bu yoruma, Kâbil kargayı göz ucu ile takip etmektedir diyebiliriz. Küçük bir şelaleden akan dere, zemin çizgisiyle birleşmektedir. Olayın geçtiği mekân, arka planını oluşturan tepenin eteklerinde verilmiştir. Tepe üzerindeki iki ağaçla, minyatürün sağ köşesinde, dere kenarına çizilen yeşil ağaç, kompozisyona derinlik hissi katmaktadır.

\section{Sonuç}

Kutsal kitaplarda yer alan ayetlerden edinilen bilgiler ışığında, hafızaları süsleyen, Hâbil ile Kâbil kıssasının metni şekillenmiştir. Bu konudaki en doğru bilgiyi Kuran-ı Kerimde Maide suresinden almaktayız. Kuran'da Hâbil ve Kâbil'in ismi geçmezken kıssanın anlatımında, Hz. Âdem'in iki oğlu şeklinde tanımlanır. İslam âlimleri, Hâbil ile Kâbil'in arasındaki anlaşmazlığa sebep olan konunun, kız meselesi olduğunu söylerken, Yahudiler toprak meselesi demiştir. Kur'an-ı Kerim anlaşmazlığa yol açan nedenden bahsetmez. Hâbil ile Kâbil bir konuda anlaşmazlığa düşerek Rablerine "kurban" sunmuşlardır. Kurban birinden kabul edilmiş, diğerinden edilmemiştir. Kurbanı kabul olmayan (Kabil), kardeşi (Habil)'i kıskanarak, onu öldüreceğini söyler ve nefsine yenilerek, bulduğu ilk firsatta kardeșinin ikazlarına rağmen onu öldürür. Kuran'da Hâbil'i öldüren Kâbil'in "Ziyana uğrayanlardan olduğu" bildirilmektedir.

Yine; Kuran'da, yüce Allah'ın, kardeşinin cesedini ne yapacağını bilmeyen Kâbil'e yeri eșeleyen iki karga göndererek, cesedi nasıl gömeceğinin öğretilmesi anlatılır. Kâbil kargaları izledikten sonra, kendini ayıplamış, karga kadar olamadığını idrak edip, acizliğini kabul ederek, pişman olduğu da, yine Kuranda aktarılmaktadır.

Kuran-ı Kerim'in yanı sıra diğer Kutsal kitaplar da geçen kıssanın, metin bilgilerinin bir kısmı birbirini doğrularken, büyük ölçüde farklılıklarda mevcuttur.

Hâbil ile Kâbil arasındaki kardeş kavgasından söz eden Kur'an ayetleri, aslında Tekvin 'deki kıssaya gönderme yapmaktadır. Çünkü konuyla ilgili ilk ayet (5/Mâide 27) Hz. Peygamber'e, "Bir gerçeğin ifadesi olarak onlara Âdem'in iki oğlunun kıssasını anlat" mealindeki bir hitapla başlamaktadır. Bu hitapta zikri geçen, "Onlar" zamirinin medlulü, tüm müfessirlerce de belirtildiği gibi, genelde Ehl-i Kitap, özelde de Yahudilerdir. (Öztürk, 2004: 161-162).

Yine kutsal kitaplarda anlatılan Hâbil ile Kâbil kıssasına benzer bazı efsanelerin, eski çağ medeniyetlerinden kalma mitolojik hikâyelerinde de yer aldığı görülür. Bu benzer anlatımların sebepleri araştırıldığında; Ömer Faruk Harman'ın bu konudaki görüşü, “Aynı hadisenin uzun tarihî seyir içerisinde çeşitli çevre ve kültürlerde farklılık kazanması tabiidir ve bu değişik varyantların temelde mevcut bir tarihî hadiseye bağlı olduğunu 
gösterir ki ilâhî dinlere göre insanlığın başlangıcl, söz konusu kıssa kahramanlarının da atası olan Âdem ile Havva'dır." Şeklindedir. (URL-1)

Kanımızca; Tüm insanlığın babası Hz. Âdem ve onun oğulları Hâbil ile Kâbil'in başından geçen bu hadisenin bilinmesi ve dilden dile aktarılarak, efsaneleri süslemesi pek tabidir. Zaman tünelinde orijinal hikâyeye, yenilikler katılması veya bazı parçaların çıkartılması ile farklılaşması da bir o kadar kaçınılmaz olmuştur diyebiliriz.

Kıssayı anlatan minyatür örnekler olayın görsel sanatlar alanında nasıl anlamlandırıldığını göstermesi bakımından oldukça önem arz etmektedir. Ağırlıklı olarak tercih edilen kompozisyon konusu; Kâbil'in kardeşi Hâbil'i öldürdükten sonraki kısımdır.

Yine çoğunlukla uygulanan minyatürlerde, Allah tarafindan gönderilen iki karga aracıllğı ile Kâbil'e kardeșinin cesedini, nasıl gömeceğinin öğretilmesi konu alınmıştır. Kompozisyon kurgusu olarak, Kâbil sırtında taşıdığı Hâbil'in cesedi ile dış mekânlarda tasarlanmıștır. Bunun yanı sıra Kâbil'in uyumakta olan kardeşi Hâbil'i öldürme anıda da çok işlenen diğer bir konudur. Kurgu; Hâbil uyur vaziyette, Kâbil ise elinde büyük bir kaya ile Hâbil'in yanı başında tasarlanmıștır. Yine Hâbil ve Kâbil'i birlikte ve tek tek gösteren ve herhangi bir konu anlatımı gerçekleştirilmeyen minyatür örneklerde bulunmaktadır. Burada kurgu; figürler üzerinde ruhsal betimlemeler şeklinde verilmiş, Hâbil güzel, llımlı ve tevekkül içinde yansıtılırken, Kâbil çirkin, sert ve öfkeli bir biçimde yorumlanmıştır.

Minyatür kompozisyonlarda yorumlanan kıssa; Hâbil, Kâbil ve kargalar ana karakterleri oluştururken, bazı minyatür örneklerde, bu ana karakterlerin yanı sıra, kanatlı melekler ve İblis (șeytan) betimlemelerine yer verilmiştir.

Minyatür örneklerde Hâbil ile Kâbil'in aralarındaki meselenin ne olduğuna dair bir betimleme yapılmadığı görülür. Bununla beraber Hâbil ve Kâbil'in Allah' a sundukları sungunun ne olduğu ile ilgi yorumlamalara da pek az yer verilmiştir. Minyatürlerde gördüğümüz sungu yorumları koyun, keçi cinsinden hayvanlar ve bazen bir demet buğday başağı biçiminde verilmiştir.

Yüzlerce yıl öncesine dayanan minyatür örneklerin eşsiz yorumlarına dokunabilmek ve ecdadın kıssaya bakış açısını, kavraya bilmek açısından bu kıymetli eserler bir hazineden farksızdır. $\mathrm{Bu}$ eserlerin araştırılarak incelenmesi hem tarihi açıdan hem de görsel sanatlar açısından bilgi dağarcığımızı yükselterek, zihnimizde yeni pencereler açacağı umulmaktadır. 


\section{KAYNAKÇA}

\section{Yazılı Kaynaklar}

Ateș, S. (1995). Kur'ân-ı Kerim tefsiri. İstanbul: Milliyet Gazetecilik.

And, M. (2007). Minyatürlerle Osmanlı-İslam mitologyası. İstanbul: Yapı Kredi.

Atuk, C. (2009). Âdem ve Havva'nın kitabı: Eski ahit apokrifasında Âdem ve Havva'nın hayatı. Hitit Üniversitesi Illahiyat Fakültesi Dergisi, 2006/2, C. V, S. 10.

Bağcl, S. - Çağman, F. - Renda, G. - Tanındı, Z. (2006). Osmanlı Resim Sanatı. İstanbul: Mas Matbacillk.

Dikbıyık, C. (2018). Günah eyleminin kökenine dair sosyolojik bir deneme Âdem Kıssası örneği. Tekirdağ Illahiyat Dergisi,4 (2), 506-538.

Milstein, R. - Ruhrdanz, K. - Schmitz, B. (1999). Stories of the Prophets-Illustrated Manuscripts of Qisas al-Anbiya. California-USA: Mazda Publishers.

Öztürk, M. (2004). Kur'an, Kitab-ı Mukaddes ve Sümer mitolojisinde Habil-Kabil Kıssası. Çukurova Üniversitesi İlahiyat Fakültesi, 4(1),161-162.

Renda, G. (1977). Türk ve İslam Eserleri Müzesi'ndeki Zübdet-üt Tevarih'in minyatürleri. Sanat Dergisi, 3(6) 58-67.

Şola, H. (2015). Muhammed Abduh'un Âdem Kıssasına yaklaşımı. Cukurova Üniversitesi Illahiyat Fakültesi Dergisi, 15(1), 203-228.

Yazır, M. H. (1979). Hak dini Kur'an dili. C. 3, İstanbul: Eser Neşriyat.

\section{Elektronik Kaynaklar}

URL-1:Hâbil ve Kābil, Hz. Âdem ile Hz. Havvâ'nın ilk iki oğlu. Ömer Faruk Harman. https://islamansiklopedisi.org.tr/habil-ve-kabil (Erişim: 05-01-2020). 